Proc. Estonian Acad. Sci. Biol. Ecol., 2002, 51, 4, 227-241

\title{
Tracing the pathways of particles settling into a small lake
}

\author{
Jaan-Mati Punning*, Tiiu Koff, Tiiu Alliksaar, and Jaanus Terasmaa \\ Institute of Ecology, Tallinn Pedagogical University, Kevade 2, 10367 Tallinn, Estonia \\ Received 4 February 2002, in revised form 11 June 2002
}

\begin{abstract}
An inventory was made of the fluxes of dry matter, pollen grains, and spherical fly-ash particles into a small mesotrophic lake. The data obtained from a two-year experiment with regularly emptied sediment traps showed that the resuspension of settled particles in a lake of a low dynamic ratio depended mostly on the seasonal changes in the thermal stratification of the lake. The inventory of matter fluxes in the lake and to sediments during the last $4-5$ years suggested that about $55 \%$ of the autochthonous organic matter would be decomposed during sedimentation. The sinking velocity of the studied particle types is low, especially so for pine pollen grains due to their morphological peculiarity.
\end{abstract}

Key words: particle fluxes, sediment traps, sedimentation, resuspension, small lake.

\section{INTRODUCTION}

The origin of settling particles and their time- and space-dependent variations in a waterbody determine the flux of matter to the sediment. Therefore, studying fluxes and composition of trapped particles in a lake is of great importance for estimating internal pollution fluxes as well as for interpreting information stored in sediments.

In many cases, the intensity of resuspension and focusing of sediments control the reliability of paleolimnological reconstructions. The application of sediment traps enables the flux of matter in the water column (Bloesch \& Uehlinger, 1986) or sediment accumulation at the bottom of the lake to be measured (Weyhenmeyer et al., 1995; Heiskanen, 1998) and helps to determine the importance of sediment resuspension in lakes with different morphometry (Stheinman \& Parparov, 1997; Mieszczankin \& Noryskiewicz, 2000). Istvanovics et al. (1992) showed that

\footnotetext{
* Corresponding author, mati@eco.edu.ee
} 
resuspension plays a leading role in the cycling of nutrients in lakes and, therefore, determines the resistance, resilience, and capability of lakes for recovery. Trap data and different model calculations have also been applied to quantify particle fluxes and resuspension in lakes with different morphometric parameters and trophy (Bloesch \& Uehlinger, 1986; Weyhenmeyer et al., 1996). These studies were concerned mainly with the fluxes of total dry matter and its organic fraction in traps exposed in different sites and depths. Davis (1968) studied sedimentation rates of pollen in lakes and concluded that pollen influx in lakes varies with factors not associated with the surrounding vegetation. These include sedimentary processes within the lake and differences between the lakes due to lake size and morphometry.

Most former studies in this field deal with large lakes $\left(>1 \mathrm{~km}^{2}\right)$. Our approach was based on the application of various indicators to distinguish the spatialtemporal fluxes of particles in a small lake. The indicators examined were dry sediment matter and atmospherically-derived particles such as pollen grains and spherical fly-ash particles (SFAP, including both spherical carbonaceous particles and inorganic ash spheres), the latter being a product of high-temperature combustion of fossil fuels. The aim of the study was to identify the main patterns in the distribution of particles with different characteristics inside the lake and their pathways to the sediments. Therefore, two-year deposition influxes of dry matter (DM), pollen, and SFAP were analysed in sediment traps and in the upper layers $(1-3 \mathrm{~cm})$ of sediments accumulated during the last $4-5$ years. Comparison of trap and sediment core data offers an opportunity to determine the time interval from the deposition of particles on the surface of the water until their final accumulation in sediments.

The study was conducted in Lake Jussi Pikkjärv (hereafter Lake Jussi), a small closed mesotrophic lake with an area of 6.1 ha, situated in northern Estonia (Fig. 1) and surrounded by mixed pine, spruce, and birch forest. The catchment of the lake is characterized by limno- and fluvioglacial sediments and large peatland areas. The lake is bordered by kames with steep slopes, except the southern side of the lake, which is bordered by an ombrotrophic mire. Lake Jussi is strongly elongated from north to south with a shoreline coefficient of 1.5. Its mean depth is $3.36 \mathrm{~m}$ and maximum depth, near the eastern shore, is $9.75 \mathrm{~m}$ (Fig. 1). According to measured runoff characteristics (Tõnisson, 1995) the calculated average residence time of water in Lake Jussi is about 4 years. Surface sediments of the lake are brownish gyttja with high water and organic matter concentrations (average $97 \%$ and $85 \%$, respectively).

\section{MATERIAL AND METHODS}

\section{Sediment traps}

The sediment trap consisted of five cylinders with aspect ratio of 5.6 (Håkanson \& Jansson, 1983; Punning et al., 2000). At every site two traps were 


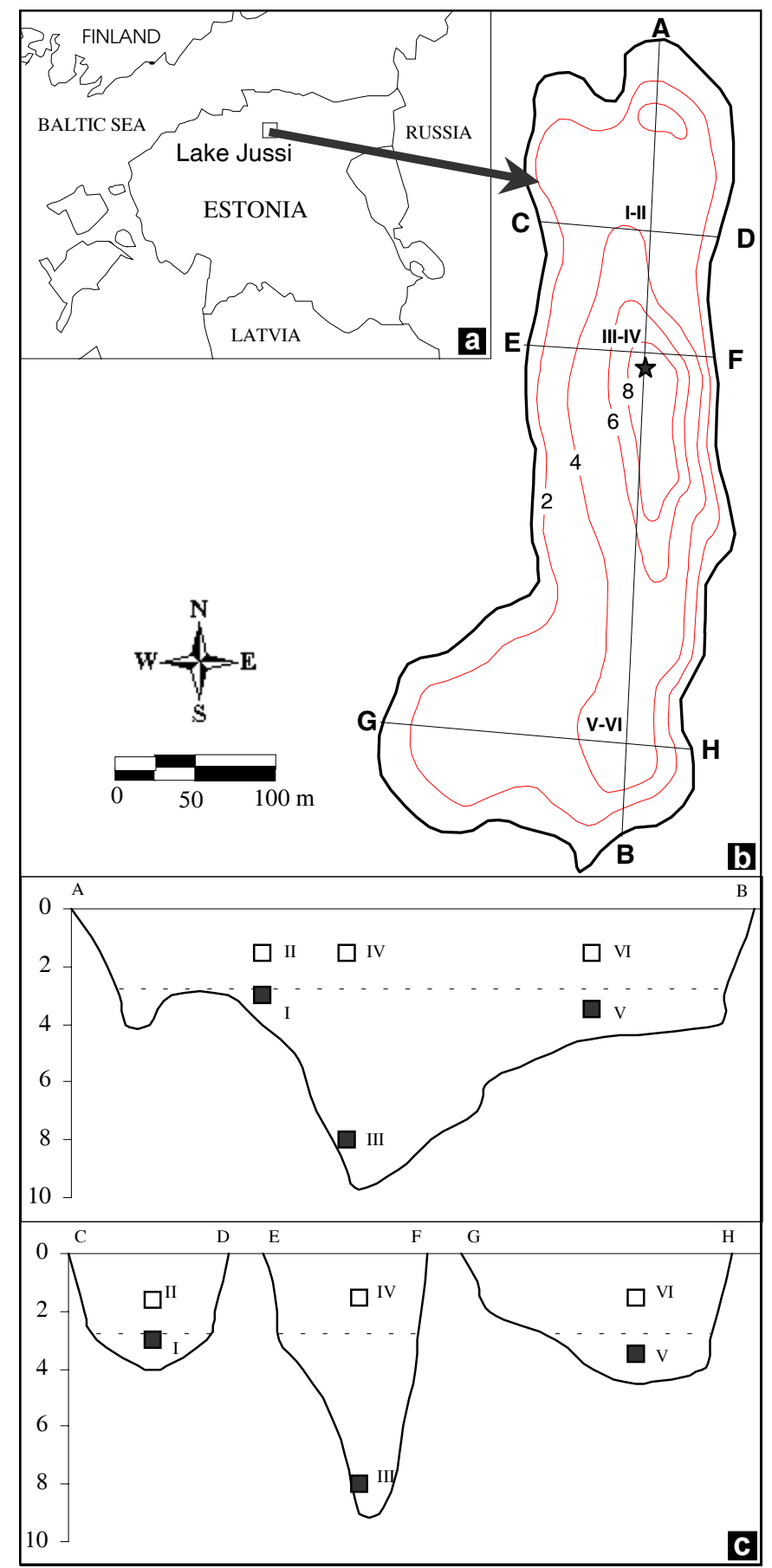

Fig. 1. Location of Lake Jussi Pikkjärv (a), the bathymetry of the lake (b) with the placement of sediment traps (I-II, III-IV, V-VI) and the sediment core $(\star)$, the studied profiles with the location of sediment traps (c) where the dashed lines denote the thermocline. 
deployed at different depths - the lower trap $1.0 \mathrm{~m}$ above the lake bottom and the upper trap $1.5 \mathrm{~m}$ below the water surface. Three pairs of traps were placed at three sites along the longest $\mathrm{N}-\mathrm{S}$ transect of the lake (Fig. 1). The experiment lasted from 6 May 1997 until 8 May 1999. The trap exposure periods were selected according to the seasonality of the lake. Over the two year period the traps were replaced 12 times.

When the traps were taken out, formalin was immediately added into the cylinders to stop bacterial processes and photosynthesis. The material in the traps was allowed to settle, water was decanted, and the residue was dried at $105^{\circ} \mathrm{C}$ to a constant weight.

A simplified method for pollen preparation was used because of a very small amount of dry matter in the traps. After adding indicators (Lycopodium spores) in order to estimate pollen concentration and influx, the samples were heated with $15 \%$ hydrogen peroxide $\left(\mathrm{H}_{2} \mathrm{O}_{2}\right)$ for $10 \mathrm{~min}$. The pollen grains were counted on one slide, and the rest of the sample was used for SFAP analyses. For SFAP counting the samples were treated with $32 \% \mathrm{H}_{2} \mathrm{O}_{2}$ according to Renberg \& Wik (1985), this was followed by addition of Lycopodium spores to calculate particle concentration (Odgaard, 1993) and influx in the samples. The fluxes of dry matter, pollen grains, and SFAP were calculated per square centimetre per day.

The trap exposure periods were combined into different seasons according to the thermal and oxygen stratification conditions in the lake (Table 1). The summer season with strong stratification lasted from the first week of May until the beginning of September. The autumn overturn season started at the beginning of September and lasted until the formation of ice on the lake in NovemberDecember. Our third observation period integrated winter and spring seasons with a permanent ice-cover on the lake and the inflow of meltwater to the lake in early spring. The influx data for different years and different seasons within both years were summarized.

Table 1. Trap exposure periods during two years of experiment

\begin{tabular}{|c|c|c|c|}
\hline Season & $\begin{array}{c}\text { Year 1 } \\
06.05 .1997- \\
07.05 .1998\end{array}$ & $\begin{array}{c}\text { Year 2 } \\
08.05 .1998- \\
05.05 .1999\end{array}$ & $\begin{array}{l}\text { Characterization of the } \\
\text { thermal stratification }\end{array}$ \\
\hline Summer & 06.05-01.09 & $08.05-31.08$ & Strongly stratified \\
\hline Autumn & $02.09-13.11$ & 01.09-15.12 & Overturn, homogenization \\
\hline Winter-spring & $14.11-07.05$ & $16.12-05.05$ & $\begin{array}{l}\text { Light inverse stratification under ice, } \\
\text { breaking of ice, and strong mixing by } \\
\text { meltwater }\end{array}$ \\
\hline
\end{tabular}




\section{Sediment core}

The coring site was situated in the deepest area of the lake (Fig. 1b). Sampling was performed with a modified Livingstone-Vallentyne piston corer and the lithology of the core was recorded in the field. The core was subsampled at continuous $1 \mathrm{~cm}$ intervals.

The content of organic matter (OM) was measured by loss-on-ignition at $550^{\circ} \mathrm{C}$. Sediment treatment for pollen and SFAP analyses was the same as for the trap samples. The results are expressed as the number of particles per gram of dry sediment.

To determine the sediment accumulation rate and the influx values of pollen and SFAP in the uppermost sediment layers, approximate dating of the sediment core was done. For that purpose the distribution curve of SFAP in a $20-\mathrm{cm}$ long sediment core and a reference layer from the time when a significant increase in the SFAP concentration started were used (Renberg \& Wik, 1985; Rose et al., 1995). Statistics on the combustion of fossil fuels in Estonia and elsewhere in Europe allowed us to date the rise in the particle profile at about 1945 (increase in fuel consumption after World War II). The age of every analysed layer was calculated by dividing the DM concentration in the layer with its mean accumulation rate.

\section{RESULTS}

The weather patterns during the two years of study differed greatly. In 1997 the spring was warmer than usual and consequently the thawing and runoff took place mainly before ice-break on the lake. In 1998 the spring was long and cool and therefore the melting of snow was not so intensive as in 1997. Also, the monthly average temperatures in summer differed, being in 1998 some $3-4{ }^{\circ} \mathrm{C}$ lower than in 1997. The differences in precipitation during the two observation years, especially during the summer months, were the most important. In 1997 the amount of precipitation was about $60-70 \mathrm{~mm}$ in June and July with a very sharp minimum in August $(<9 \mathrm{~mm})$. In contrast, the summer of 1998 was extremely rainy (150-220 $\mathrm{mm} \mathrm{month}^{-1}$ in June-August).

\section{Sediment traps}

In the sediment traps the DM, pollen of birch (Betula), pine (Pinus), and some herbs, and SFAP were analysed. The variations in the total amount of DM deposition between years and between seasons at different depths are considerable and are mostly determined by the changes in the productivity of the lake. The total DM influx for the first year was 1.6 times as high as for the second year (Fig. 2). 


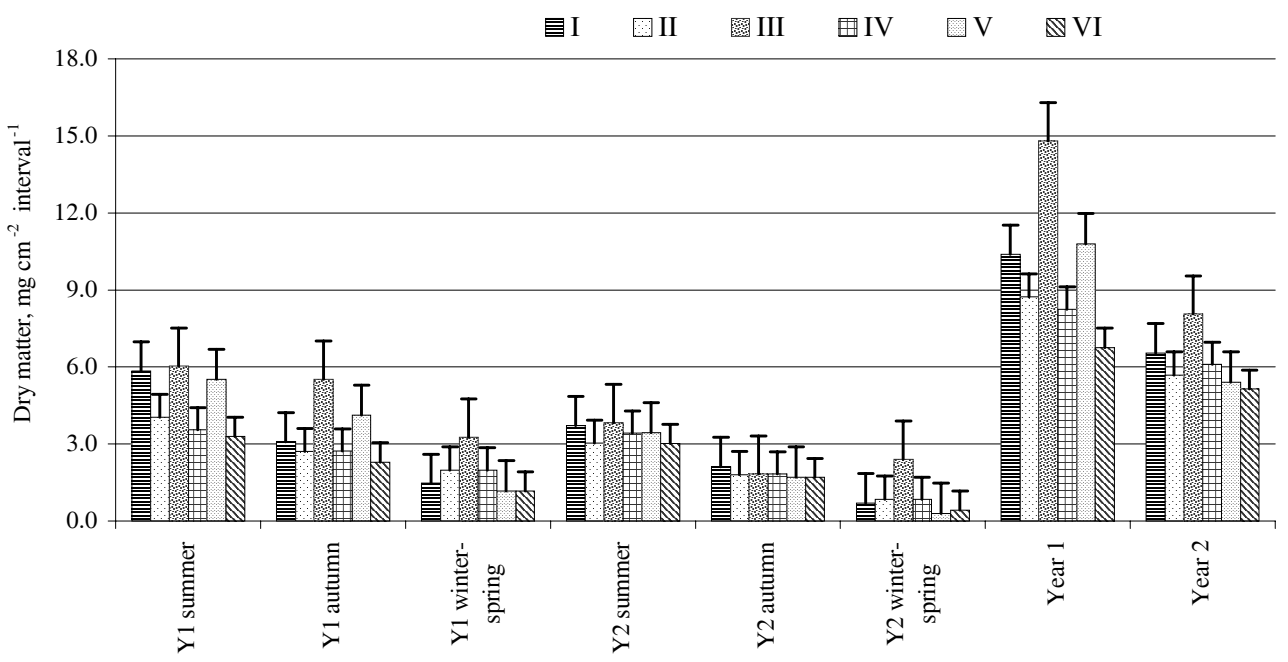

Fig. 2. Influx of dry matter with standard errors into the traps (I-VI) during different seasons and both study years (see also Fig. 1 and Table 1).

For both years, the difference in the content of DM between the upper traps (II, IV, VI) within one season was small (up to 20\%). However, essential variations were recorded in the lower traps (I, III, V) depending on the exposure depth of the trap (Fig. 1). The differences between the lower and upper traps were greater in 1997-98 than in 1998-99.

The dominant trees in the surrounding vegetation are pine and birch, and their pollen account for $80 \%$ of the total arboreal pollen in Lake Jussi sediments. Therefore, the current study focused on these two pollen types and the relationship between their seasonal flux and the different flowering periods of the trees. Meteorological conditions determine the flowering of these tree species, and thus the temporal production of pollen as well as the influx of pollen grains into the sediment traps depends on weather conditions. According to long-term observations in Estonia the highest atmospheric values of birch pollen occur from the middle of April until the first decade of May. Pine pollen production reaches its peak a month later, from the middle of May until the end of June (Saar, 1996). Therefore, the influx of these two main pollen types into the lake has a temporal difference, which is also clearly seen from the seasonal distribution of birch and pine pollen grains in the sediment traps (Figs. 3 and 4). These data also demonstrate differences between the two observation years - during the warmer spring of 1997 (Year 1) the flowering of birch was earlier than in 1998 (Year 2) when large amounts of this pollen were deposited into traps in May and June. During the autumn the influx of birch pollen was very small (Fig. 3), indicating the low rate of redeposition of birch pollen at that time. 


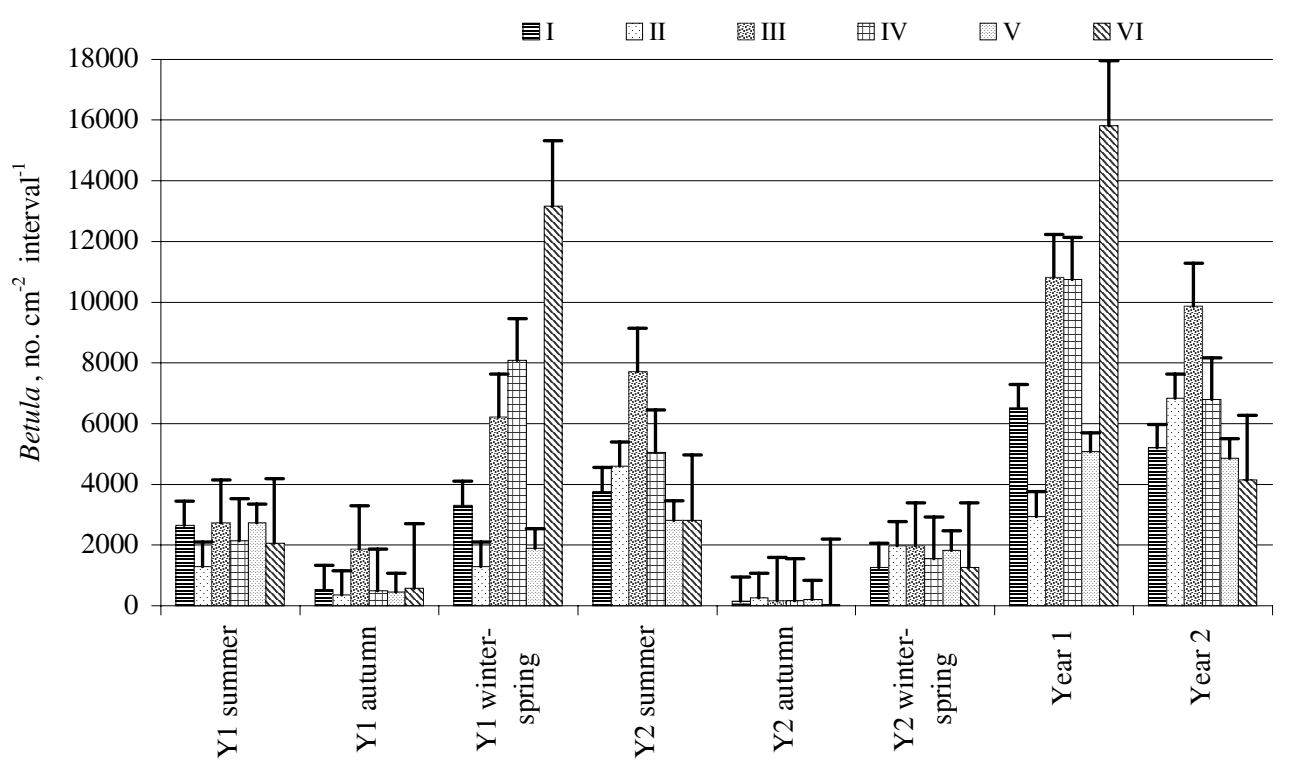

Fig. 3. Influx of Betula pollen with standard errors into the traps (I-VI) during different seasons and both study years (see also Fig. 1 and Table 1).

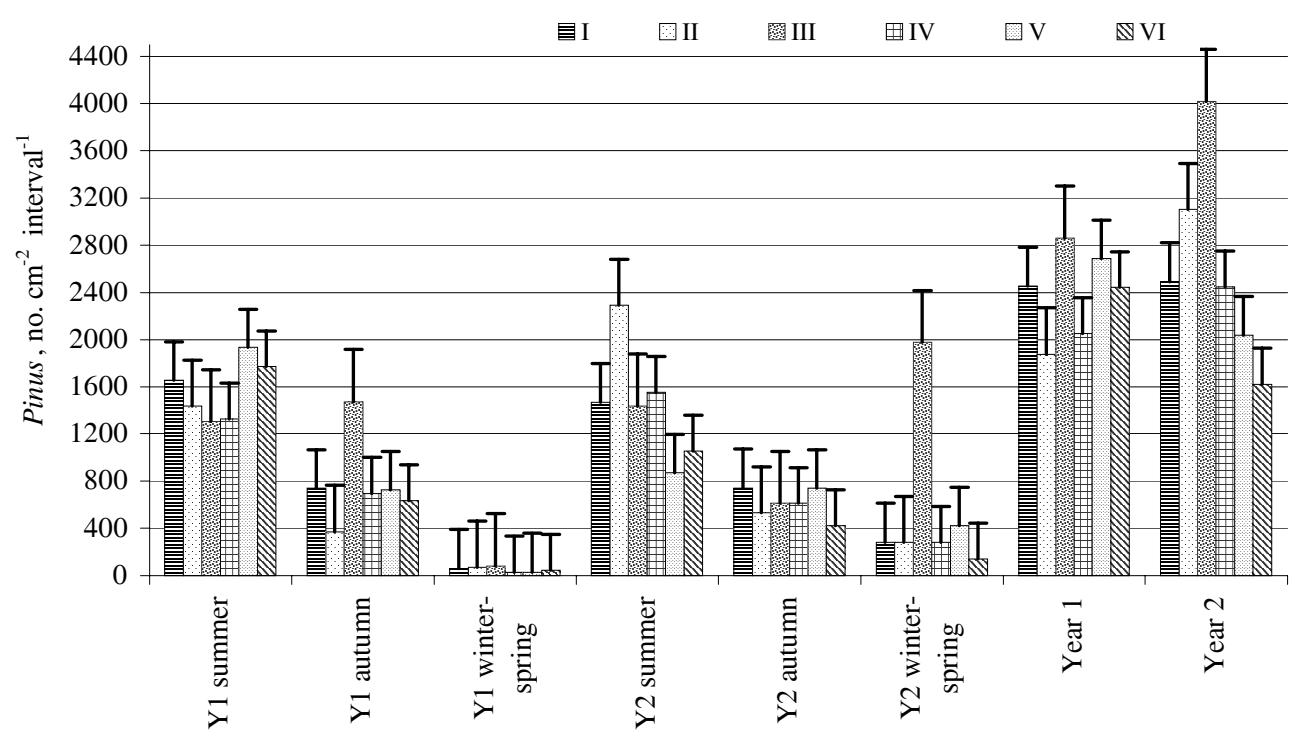

Fig. 4. Influx of Pinus pollen with standard errors into the traps (I-VI) during different seasons and both study years (see also Fig. 1 and Table 1). 
The amount of pine pollen in autumn traps was strikingly great. After the intensive flowering period (May-June) the number of pine pollen in the upper traps exceeded that in the lower traps (Fig. 5). It took 1-2 months before the amount of pine pollen in the lower traps exceeded that in the upper traps. In the case of birch the amount of pollen in the upper and lower traps was more uniform and temporal differences in the vertical distribution are apparent only in the deepest area (traps III and IV) (Fig. 3).

As there are no major emitters of SFAP close to Lake Jussi, the flux of particles into this lake should be determined by atmospheric long-distance transport, which has been quite constant over time. The data obtained support this assumption: the total amounts of particles deposited into the upper and lower traps during 1997-98 and 1998-99 are similar (Fig. 6). However, there are significant temporal differences in the values within the two years. During the summer and autumn seasons the fluxes were relatively small and practically uniform in all traps. The dominant flux occurred during the winter-spring season, especially during a short period after the ice-break and inflow of meltwater that includes winter deposition. The differences in the influx values of the upper and lower traps are significant only during this period (Fig. 6). Analysis of the differences in the influx values of upper and lower traps for shorter periods revealed for some exposure periods (June 1997, May-July 1998, and May 1999) higher influx into the upper trap than into the lower one at the site (Fig. 7). A month later the SFAP reached also the lower traps in the shallower part of the lake (traps V and I) and after 90 days they had reached the deepest trap (III).

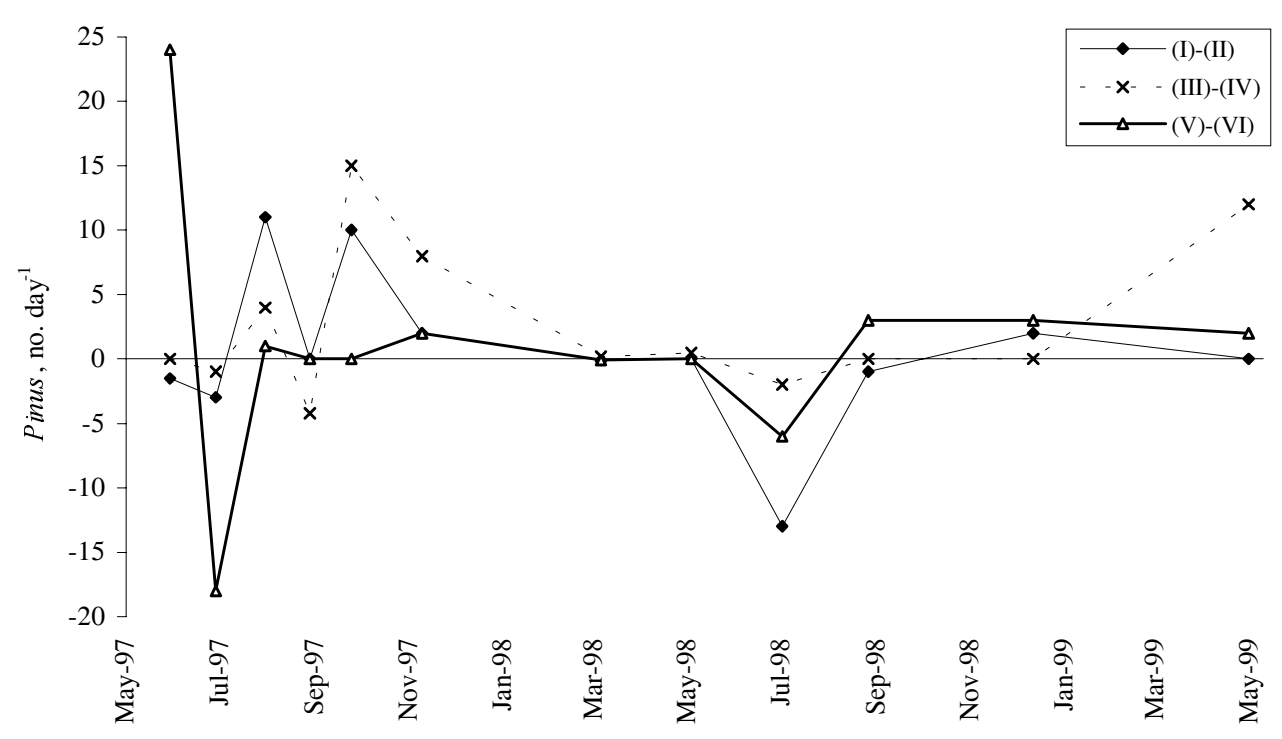

Fig. 5. Differences in the mean daily influx of Pinus pollen grains between lower (I, III, V) and upper (II, IV, VI) traps during single exposure periods (months and years are given below) (see also Fig. 1). 


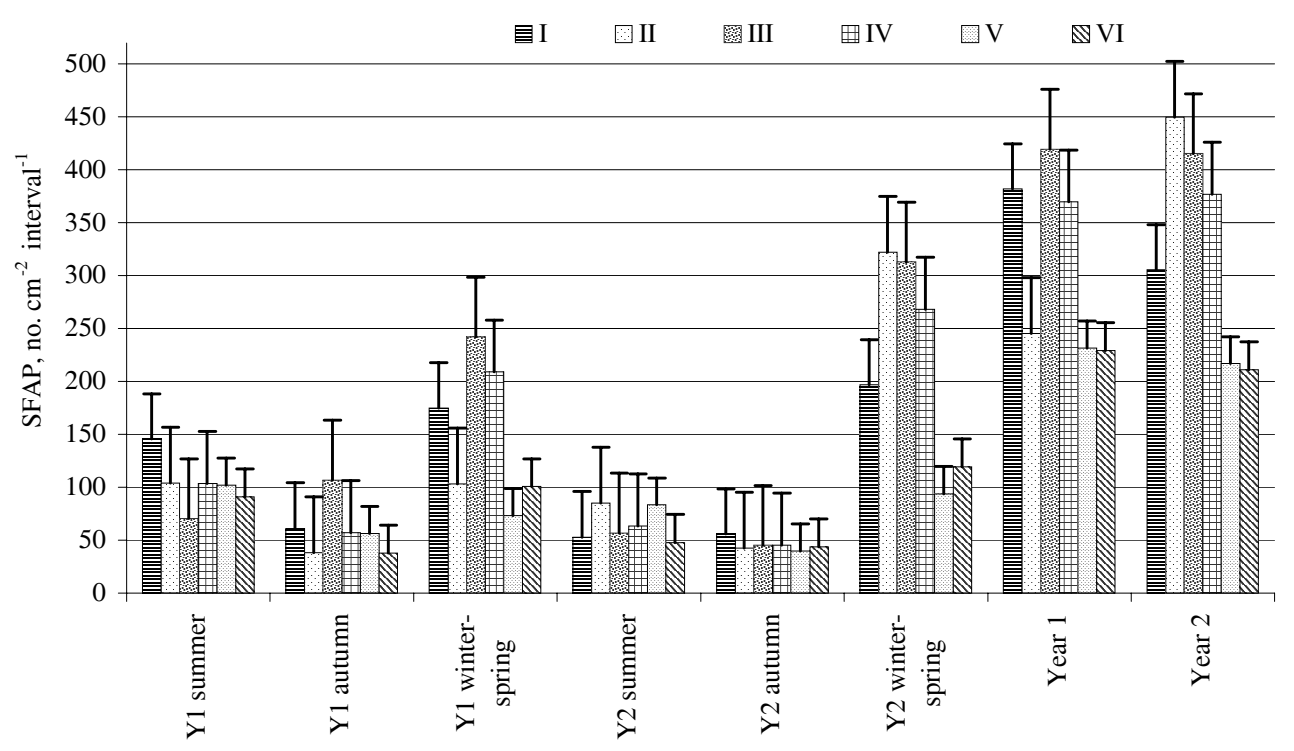

Fig. 6. Influx of spherical fly-ash particles (SFAP) with standard errors into the traps (I-VI) during different seasons and both study years (see also Fig. 1 and Table 1).

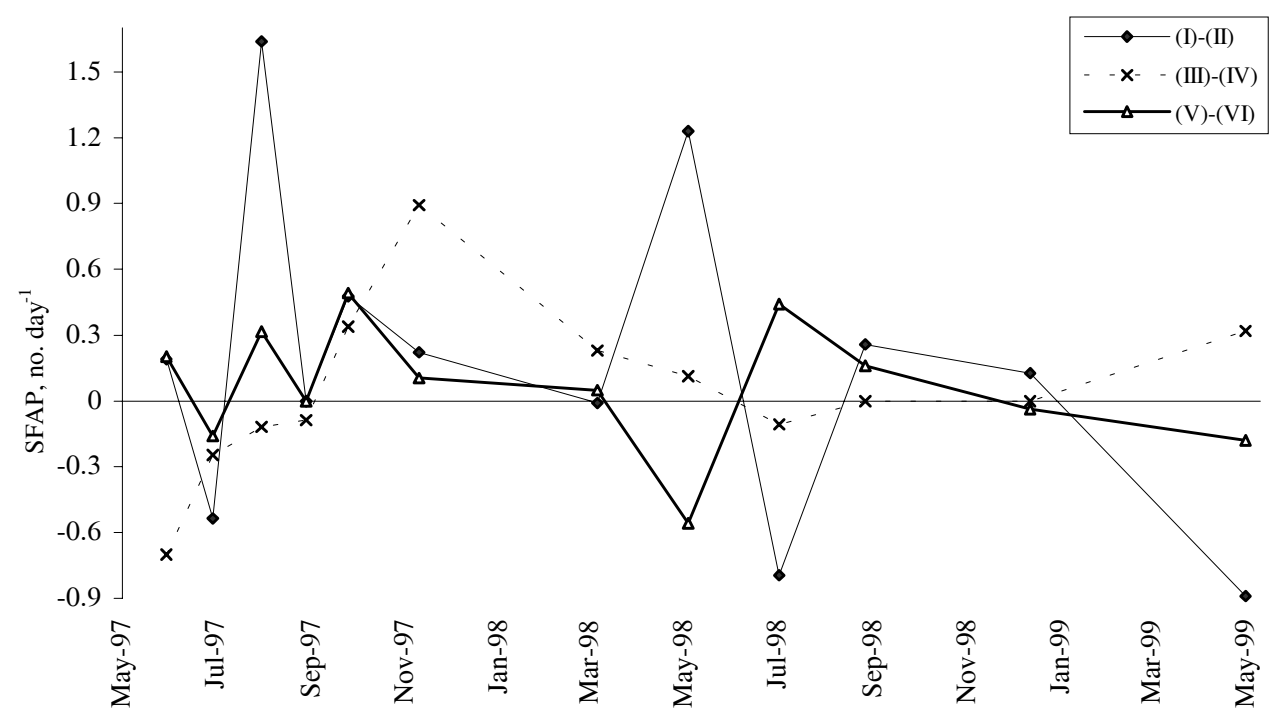

Fig. 7. Differences in the mean daily influx of spherical fly-ash particles (SFAP) between lower (I, III, V) and upper (II, IV, VI) traps during single exposure periods (months and years are given below) (see also Fig. 1). 


\section{Sediment core}

The SFAP distribution profile in the uppermost $20 \mathrm{~cm}$ of the sediment core (Fig. 8) is typical of the lakes in northern Estonia and shows similar trends with the fuel combustion statistics in that region (Punning et al., 2000). This enables the use of the SFAP curve for indirect dating of single sediment layers. Comparison of the SFAP distribution curve with data on the combustion of fossil fuels allows the sediment layer with the rapid increase in the SFAP concentration at a depth of $13 \mathrm{~cm}$ to be dated at around 1945 (Fig. 8).

Above this reference layer the calculated average accumulation rate of DM in the core is $7.5 \mathrm{mg} \mathrm{cm}^{-2} \mathrm{yr}^{-1}$, and the accumulation time for a $1 \mathrm{~cm}$ thick sediment layers is from 0.6 years in the surface up to 5 years at a depth of $13 \mathrm{~cm}$. In order to compare the mean influx values of DM in sediment traps with the integrated mean influx value into sediments it is necessary to take into account the proportion of sediment accumulation area in the lake bottom in relation to the erosion and transport area. Calculations using the formula of Håkanson \& Jansson (1983) show that in the case of Lake Jussi the sediment accumulation area is about $70 \%$ of the whole lake bottom area. Therefore all influx values in sediments in Table 2 were multiplied by 0.7 .

The concentration of OM varies from $83 \%$ to $87 \%$ in the upper layers of sediments, the average value being about $85 \%$. Thus, according to the mean sediment accumulation rate of DM (Table 2), the annual accumulation of OM is about 3.9 and of mineral matter about $0.7 \mathrm{mg} \mathrm{cm}^{-2}$. The variations in the

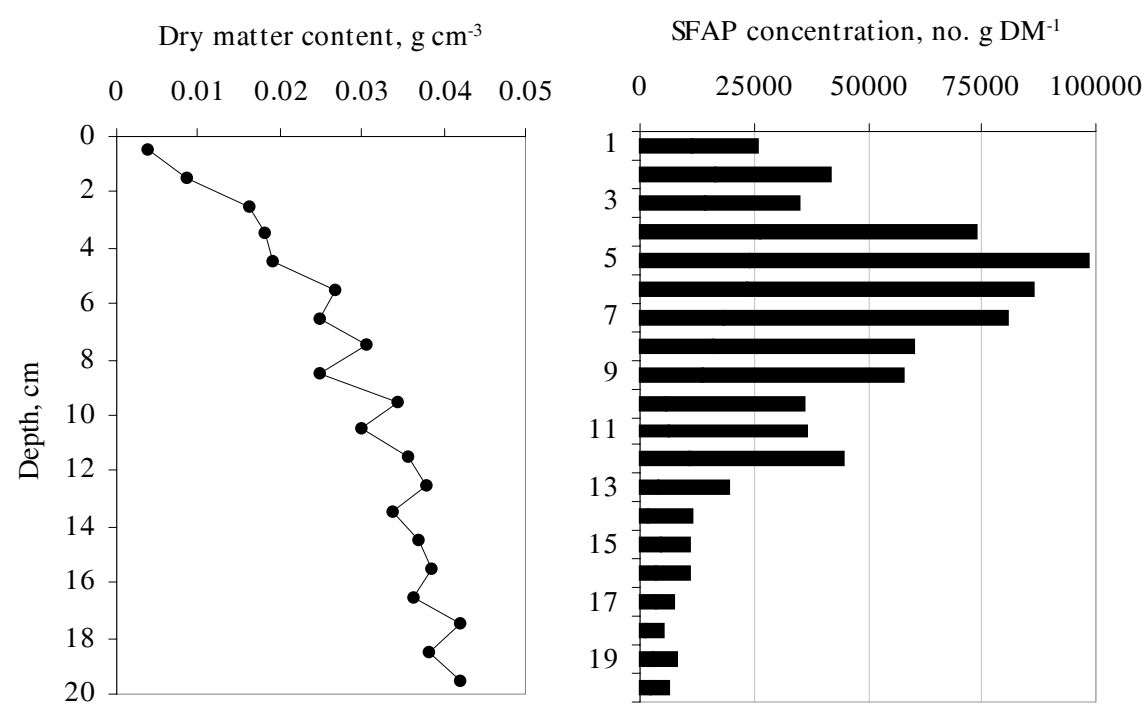

Fig. 8. Distribution of dry matter and spherical fly-ash particles (SFAP) in the sediment core of Lake Jussi Pikkjärv. 
Table 2. Accumulation rate of DM, OM $\left(\mathrm{mg} \mathrm{cm}^{-2} \mathrm{yr}^{-1}\right)$, SFAP, Betula and Pinus pollen (all in no. $\mathrm{cm}^{-2} \mathrm{yr}^{-1}$ )

\begin{tabular}{l|c|c|c|c|c|c}
\hline \multicolumn{1}{c|}{ Depth, cm } & Time, yr & DM & OM & SFAP & Betula & Pinus \\
\hline $0-1$ & 0.6 & 4.6 & 3.9 & 120 & 4200 & 4830 \\
$1-2$ & 1.3 & 4.6 & 3.9 & 190 & 4270 & 4870 \\
$2-3$ & 2.5 & 4.6 & 3.9 & 160 & 6160 & 6510 \\
Mean & 4.4 in total & 4.6 & 3.9 & 160 & 5330 & 5800
\end{tabular}

annual influx values of SFAP and birch and pine pollen into sediments were less than $30 \%$ of the mean values during the last $4-5$ years (Table 2). These interannual differences, especially in the case of pollen influxes, reflect mainly the impact of meteorological conditions on flowering and also changes in the intensity of transport from the catchment.

\section{DISCUSSION}

A key problem in understanding biogeochemical cycling in lakes and the interpretation of lake sediment records is the estimation of the proportion of resuspended matter in the fluxes of different particles. Weyhenmeyer (1996) found that the contribution of resuspended particulate matter to the total flux of settling material is $47-92 \%$. However, it must be pointed out that all lakes studied by Weyhenmeyer had a higher dynamic ratio (the ratio of the average depth to the square root of lake area) than Lake Jussi (up to 0.55 and 0.08 , respectively) and therefore in our case wind/wave activity did not play an essential role in resuspension.

There is a general similarity in the patterns of the influxes of DM and pollen grains within a year and the differences between years indicate the importance of external factors, the most important of which are differences in meteorological conditions between the study years. Influxes of SFAP are comparable for two different years as they do not depend significantly on weather conditions.

The most obvious difference was recorded in the total DM influx into sediment traps - it was about 1.6 times higher in 1997-98 than in 1998-99. The difference is especially apparent for the summer and autumn seasons in 1997 (Y 1, Fig. 2). During these exposure periods a direct relationship exists between the amount of DM in the lower traps and their depth in the water column. The difference in the mean DM influx between the lower and upper traps is about 1.4-fold (Table 3). It can be caused by phytoplankton productivity in the water column below the upper trap. In Lake Jussi water transparency is $1.5-2.5 \mathrm{~m}$ during summer months and hypolimnetic anoxia is below 5-6 m. Therefore the higher influx of DM into the lower traps should not be connected only with resuspension of sediments. If we consider the important role of primary production in the settling matter and assume that during the summer stratification the 
Table 3. Influxes of DM, OM ( $\left.\mathrm{mg} \mathrm{cm}^{-2} \mathrm{yr}^{-1}\right)$, SFAP, Betula and Pinus pollen (all in no. $\mathrm{cm}^{-2} \mathrm{yr}^{-1}$ ) into sediment traps (2-year average) and bottom sediments (4-5-year average)

\begin{tabular}{l|l|l|l|l|l}
\hline \multicolumn{1}{c}{ Depository } & DM & OM & SFAP & Betula & Pinus \\
\hline Upper traps & 6.8 & 6.15 & 310 & 7880 & 1790 \\
Lower traps & 9.3 & 8.65 & 330 & 7050 & 2760 \\
Sediments & 4.6 & 3.9 & 160 & 5330 & 5800
\end{tabular}

proportion of resuspended matter in the upper traps is low, then the proportion of resuspended particles embracing the whole vertical profile will not be over $30 \%$.

The mean influx of DM into sediments was much smaller than into traps (Table 3). If we assume that this has been caused by the decomposition of OM during the sedimentation process while the influx of mineral matter into sediment traps is the same as into bottom sediments (about $0.7 \mathrm{mg} \mathrm{cm}^{-2} \mathrm{yr}^{-1}$ ), then ca $55 \%$ of OM must have been decomposed.

The rather uniform values of pollen grains in the upper traps at all study sites in Lake Jussi show that the distribution of pollen over the lake surface is even, with the exception of a major increase in the deposition of birch pollen into trap VI in spring 1998 (Fig. 3).

The influx of Betula and Pinus pollen into sediment traps in Lake Jussi showed intraannual differences depending on the weather conditions. As the flowering times for the tree species studied do not coincide (April-June for birch and May-July for pine), the deposition of their pollen grains into traps takes place at different times in the annual cycle of the thermal stratification of the lake (Figs. 3 and 4).

The flux of birch pollen is clearly seen in the traps of spring and summer seasons comprising about 70-80\% of the annual total (Fig. 3). In 1998 the major part of the birch pollen was produced before May; this was recorded in the upper traps of the season. In the lower traps the maximum amount of trapped birch pollen was reached at the beginning of stratification, mainly in June. This suggests that the sinking velocity of birch pollen is comparable with that of SFAP and the long-term average could be estimated as $1 \mathrm{~cm} \mathrm{day}^{-1}$. The fact that during the autumn overturn period the accumulation of birch pollen was low and uniform (less than 5\% of the annual total) indicates that resuspension in the lake is low. This conclusion is also supported by comparable data of the annual influx values in the upper and lower traps (Table 3).

A special case is represented by saccate conifer grains, which may remain on the water surface for a long time. On the other hand, once the air bladders of pine pollen grain have filled with water they sink very fast (Peck, 1973). In the case of Lake Jussi the flowering time and the influx of pine pollen are evident in traps of the summer stratification season, mainly in May-June (Fig. 4). The small influx values during winter-spring show that resuspension of pine pollen was low when the intensity of the inflow of meltwater after ice-break was low in 1997, while a 
more intensive meltwater inflow is related to an increase in resuspended pine pollen as it was in trap III in 1999. Also the presence of pine pollen in traps exposed in September-November in both years was most probably caused by resuspension. Thus it seems that the resuspension of the pine pollen is higher than that of birch. One of the most reliable explanations for this might be the morphological singularity of pine pollen which causes their floating and undertrapping. According to the data of Gardner (1980) the undertrapping is obvious if the sinking velocity of particles is lower than $4-5 \mathrm{~cm} \mathrm{~s}^{-1}$.

The influx of SFAP might be treated as pulse-like: most of the particles fall into the lake in spring after the thawing of the ice-cover on the lake. In 1999 more than $60 \%$ of the annual load of particles was introduced into the lake in spring (Fig. 6). As the results show, at first the influx of SFAP increased in the upper traps, and a month later the accumulation of particles in the lower traps exceeded that in the upper traps, analogously with the behaviour of birch pollen. In the lower trap from the deepest area of the lake (trap III), the number of particles exceeded the relevant number in the upper trap only at the end of the summer stratification period. This means that the settling velocity of the particles is low (ca $1 \mathrm{~cm} \mathrm{day}^{-1}$ ), at least during the stratification season when the thermocline might retard the sinking of some particles (Dean et al., 1999). This supports the idea presented earlier that during stratification the reverse flux of matter from the hypolimnion to the epilimnion is very low or even absent. The rather low number of SFAP settled in traps during the autumn overturn period (ca $10 \%$ of the total annual deposition) indicates that the thermal homogenization of the water column does not cause strong resuspension and redistribution of particles within the lake.

The inventory of pollen grains and SFAP showed that the annual influx of birch pollen and SFAP settled into sediment traps is greater and that of pine pollen smaller than the relevant amounts accumulated in bottom sediments. Håkanson \& Jansson (1983) demonstrated that the relationship between the residence time of water and the residence time of substances is most important in lake sedimentological contexts and can determine the turnover rate of particles. Because of the high residence time of the water in Lake Jussi (approximately 4 years) the rate of the deposition of particles with diverse morphological characteristics and settling velocity can be very different.

\section{CONCLUSIONS}

Our results showed a relatively low resuspension of settled particles in a lake of small dynamic ratio. In the case of total dry matter it reached $30 \%$ but for SFAP and birch pollen it did not exceed $10 \%$ of the total annual influx into the lake. The role of resuspension is greater in the traps exposed below the thermocline and is mainly determined by the near-bottom transport fluxes (focusing), which are stronger in the deepest part of the lake in areas with steep 
slopes. Resuspension depends on the characteristics of a particle (saccate pollen grains of pine can be especially affected) and on the seasonal changes of the thermal stratification of the lake. The results show that small lakes where the wind/wave activity does not play a significant role should be preferred in order to obtain accurate palaeogeographical information.

The inventory of the fluxes of matter in the water column and that deposited into sediments during the last 4-5 years suggests that about $55 \%$ of the organic matter will be decomposed during sedimentation. The sinking velocity of the studied particle types was low during the stratification period (estimated average for birch pollen and SFAP being about $1 \mathrm{~cm} \mathrm{day}^{-1}$ ). In the case of pine pollen the results were contradictory due to the morphological peculiarity of these pollen grains. The annual influx of birch pollen and SFAP settled into sediment traps is greater and that of pine pollen smaller than the relevant amounts accumulated in bottom sediments, which may be explained by different turnover rates of these particles.

\section{ACKNOWLEDGEMENTS}

The study was supported by target-financed project of the Estonian Ministry of Education and the Estonian Science Foundation (grant No. 3773). We would like to thank Prof. Rick Battarbee for his helpful and constructive review of an earlier version of this paper.

\section{REFERENCES}

Bloesch, J. \& Uehlinger, U. 1986. Horizontal sedimentation differences in a eutrophic Swiss lake. Limnol. Oceanogr., 31, 1049-1109.

Davis, M. 1968. Pollen grains in lake sediments: redeposition caused by seasonal water circulation. Science, 162, 796-799.

Dean, J. M., Kemp, A. E. S., Bull, J., Patterson, G. \& Zolitschka, B. 1999. Taking varves to bits: scanning electron microscopy in the study of laminated sediments and varves. J. Paleolim., 22, 121-136.

Gardner, W. D. 1980. Sediment trap dynamics and calibration: a laboratory evaluation. J. Mar. Res., 38, 17-39.

Håkanson, L. \& Jansson, M. 1983. Principles of Lake Sedimentology. Springer-Verlag, Berlin.

Heiskanen, A.-L. 1998. Factors governing sedimentation and pelagic nutrient cycles in the northern Baltic Sea. In Monographs of the Boreal Environment Research, Vol. 8. Finnish Environment Institute, Helsinki.

Istvanovics, V., Pettersson, K., Pierson, D. C. \& Bell, R. 1992. Evaluation of phosphorus deficiency indicators for summer phytoplankton in Lake Erken. Limnol. Oceanogr., 37, 890-900.

Mieszczankin, T. \& Noryskiewicz, B. 2000. Processes that can disturb the chronostratigraphy of laminated sediments and pollen deposition. J. Paleolim., 23, 129-140.

Odgaard, B. V. 1993. The sedimentary record of spheroidal carbonaceous fly-ash particles in shallow Danish lakes. J. Paleolim., 8, 171-187.

Peck, R. M. 1973. Pollen budget studies in a small Yorkshire catchment. In Quaternary Plant Ecology (Birks, H. J. B. \& West, R. G., eds.), pp. 43-60. Blackwell Scientific Publ., Oxford. 
Punning, J.-M., Koff, T. \& Alliksaar, T. 2000. Matter fluxes in Lake Matsimäe (Central Estonia) estimated from traps and sediment records. Oil Shale, 17, 184-200.

Renberg, I. \& Wik, M. 1985. Soot particle counting in recent lake sediments: an indirect dating method. Ecol. Bull., 37, 53-57.

Rose, N. L., Harlock, S., Appleby, P. G. \& Battarbee, R. W. 1995. The dating of recent lake sediments in the United Kingdom and Ireland using spheroidal carbonaceous particle concentration profiles. Holocene, 5, 328-335.

Saar, M. 1996. Aerobioloogiline monitooring. In Keskkonnaseire 1995, pp. 112-114. Eesti Vabariigi Keskkonnaministeerium, Info- ja Tehnokeskus, Tallinn.

Stheinman, B. S. \& Parparov, A. S. 1997. An approach to particulate matter transfer studies in littoral zones of lakes with changing morphometry. Water Sci. Technol., 36, 199-205.

Tõnisson, A. 1995. Jussi järvestiku maastikuline iseloomustus ja arengutendentsid. In Eesti Geograafia Seltsi aastaraamat, Vol. 29, pp. 17-33. Teaduste Akadeemia Kirjastus, Tallinn.

Weyhenmeyer, G. A. 1996. The Significance of Sediment Resuspension in Lakes. Comprehensive Summaries of Uppsala Dissertations from the Faculty of Science and Technology 225. Acta Univ. Ups.

Weyhenmeyer, G. A., Meili, M. \&. Pierson, D. C. 1995. A simple method to quantify sources of settling particles in lakes: resuspension versus new sedimentation of material from planktonic production. Mar. Freshwater Res., 46, 223-231.

Weyhenmeyer, G. A., Håkanson, L. \& Meili, M. 1996. A validated model for daily variations in the flux, origin and distribution of settling particles within lakes. In Weyhenmeyer, G. A. The Significance of Sediment Resuspension in Lakes. Comprehensive Summaries of Uppsala Dissertations from the Faculty of Science and Technology 225. Acta Univ. Ups.

\section{Sestoni liikumisteed väikejärves}

\section{Jaan-Mati Punning, Tiiu Koff, Tiiu Alliksaar ja Jaanus Terasmaa}

Settelõksude kaheaastase eksperimendiga koguti andmestik kuivaine, õietolmu ja lendtuhaosakeste liikumise kohta väikeses mesotroofses Jussi Pikkjärves. Saadud tulemused näitasid, et setteosakeste resuspensioon väikese dünaamilise suhtega järves sõltub peamiselt järve termilisest stratifikatsioonist ja selle sesoonsest muutumisest. Aastasest kuivaine sissekandest ligi 30\% võib olla resuspendeerunud, lendtuhaosakeste ja kase õietolmu puhul ei ületa vastav näitaja $10 \%$. Resuspensioonile altid on männi õietolmuterad, millel on õhupõied. Settelõksude ja põhjasette sestonivoogude võrdlemisel selgus, et umbes 55\% orgaanilisest ainest laguneb juba settimise käigus. Leiti, et uuritud sestoniosakeste settimiskiirus on madal, seda eriti suvise stratifikatsiooni korral, kui termokliin takistab osakeste sadenemist. Morfoloogiliste iseärasuste tõttu erines männi õietolmu settimine muu materjali omast tunduvalt. 